\title{
CÉDULA DE FELIPE IV SOBRE EL DERECHO DE LA MEDIA ANATA
}

\author{
Ma Belén Piqueras García \\ Universidad de CÁdiz
}

\section{RESUMEN}

En este artículo realizamos el estudio de un documento generado, a partir de una Cédula emitida por Felipe IV, con la finalidad de hacer efectivo en Cádiz el cobro de un impuesto, el de la media anata.

PALABRAS CLAVE: Cédula real, Felipe IV, Cádiz, impuesto, media anata.

\section{ABSTRACT}

In this article we make the study of a document generated by a Royal Charter issued by Philip IV for the purpose of giving effect to Cadiz in the recovery of a tax on the average anata.

KEY WORDS: Royal Charter, Philip IV, Cadiz, tax, half anata. 


\section{Introducción}

Hace ya unos años tuve la ocasión de visitar por vez primera la Biblioteca del Seminario de Cádiz, quedé impresionada por la riqueza de sus fondos, no debida únicamente a la cantidad de ejemplares que albergaba, sino especialmente por la antigüedad y calidad de gran número de ellos, por aquellos años aún sin organizar. A partir de aquella primera visita y gracias al visto bueno del que por entonces fuera su Rector, D. Jesús García Cornejo, pude volver, junto con otros compañeros, a buscar en principio un libro que creíamos podría estar allí, en esa búsqueda, en la que agradezco la paciencia del en aquel momento seminarista y hoy ya sacerdote, D. Alfonso Gutiérrez Estudillo, que siempre encontraba un hueco en su apretado horario para atendernos y acompañarnos, encontramos, dispersas entre los libros, algunas carpetas que contenían documentos que llamaron nuestra atención, algunos de los cuales nos permitieron fotografiar e incluso fotocopiar en el mismo Seminario ${ }^{1}$. Entre ellos se conservaba el cuaderno que será objeto del presente estudio y que, en principio, llamó nuestra atención por la variedad gráfica desplegada en sus hojas.

El cuaderno comienza incluyendo la copia impresa de una Cédula Real, que ocupa las dos primeras hojas, a partir de ella, y en aras a hacer efectiva la disposición de su tenor, se desarrolla el resto del contenido, el escrito municipal.

La cédula original fue realizada en Madrid en 1632, quedando en poder de Don Pedro Marmolejo, del Consejo de su Majestad, y la copia aparece fechada igualmente en Madrid, pero ya en el año 1633. Por tanto se trata de una Cédula Real de Felipe IV.

Su contenido versa sobre el cobro del derecho de media anata que se intentaba hacer efectivo, aplicándolo a cualquier oficio y en cualquier lugar.

El cuadernillo está realizado en papel, tamaño folio, y lo integran veintiuna hojas escritas por ambas caras y cosidas entre ellas con hilo bramante, presentando en la actualidad un buen estado de conservación.

El objetivo que perseguimos en este estudio es sacar a la luz el documento, Cédula y escrito municipal, dando a conocer su contenido como paso previo para más adelante, en un posterior estudio, volver a abordarlo desde la óptica paleográfica-diplomática, reparando especialmente en sus caracteres externos y en concreto en la variada grafía que presenta, obra indudablemente de distintas manos.

Creemos que la presentación de esta Cédula de Felipe IV, junto con el resto de hojas a ella anexadas, puede ser interesante dado que hoy por hoy no tenemos noticia de la conservación de la Cédula original. Nuestras pesquisas por dar con su paradero han resultado hasta ahora infructuosas, ni en Simancas, ni en el Archivo General de Indias, hemos conseguido localizarla. Por el contrario si hemos encontrado referencia a ella en el Archivo Histórico Municipal de Cádiz, en el Libro de Actas nº 10016 que abarca desde 26 de Diciembre de 1631 hasta 22 de Diciembre de $1633^{2}$.

1 Dos de ellos ya fueron objeto de estudio: PIQUERAS GARCÍA, Ma Belén, “certificación de armas del apellido Oviedo”, publicado en la Revista Emblemata, Zaragoza, 2005, pp. 83-111. Y MORGADO GARCÍA, Arturo, PIQUERAS GARCÍA, Ma Belén, "El libro de familia de los Ayllón-Mallorgas (Medina Sidonia, siglos XVI-XVIII)”, publicado en la Revista Trocadero. Cádiz, 2006, pp. 139-148.

2 En la sesión de cabildo del día 27 de enero de 1633, según puede comprobarse en el Anexo presentado, aparece recogida la noticia de la cédula emitida por el Monarca, insertando su íntegra transcripción, en concreto entre las páginas 152 a $159 v^{\circ}$. 
La presentación de esta pieza documental, aún a sabiendas de su carácter exiguo, puede aportar datos de interés, que quizás podrían tomarse en consideración, a la hora de realizar un análisis de la administración hacendística municipal gaditana desde, según palabras de González Beltrán, “la dicotomía intervención estatal-autonomía de gestión local”3.

\section{Análisis del contenido documental}

\section{Cédula de Felipe IV}

Tanto la Cédula original como su posterior copia fueron expedidas en Madrid en la primera mitad del siglo XVII, el 26 de diciembre de 1632 la primera y al mes siguiente, el doce de enero de 1633, la siguiente, época correspondiente al reinado de Felipe IV y bajo la influencia de su poderoso valido Conde-Duque de Olivares ${ }^{4}$. El documento viene a ser una muestra que evidencia la situación por la que se atravesó durante estos años, por un lado se perseguía un ambicioso proyecto de reforma: recuperar rentas enajenadas, control sobre el gasto público, ordenamiento y estructuración del sistema impositivo, etc. Proyecto de reforma que de haberse podido materializar plenamente hubiera afectado a buena parte de las instituciones y en concreto a la Hacienda. Y por otro el endeudamiento de la Monarquía dada la situación bélica en la que se veía inmersa. Ambos motivos conducen a lo que se persigue con esta cédula, obtener beneficios económicos que pudieran contribuir a paliar los escasos recursos de la Hacienda, en definitiva a paliar la crisis de la Monarquía en esta época "permanentemente

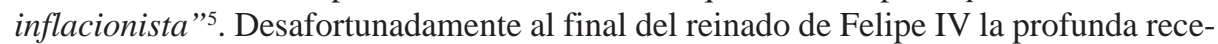
sión, crisis y cuestionamiento de la autoridad monárquica fue el panorama que quedó dibujado.

La copia impresa de la Cédula de Felipe IV inicia el cuadernillo objeto de estudio. En ella el Rey se dirige al Doctor Don Pedro Marmolejo, "Cauallero de la Orden de Santiago, del mi Consejo, asesor, y Consejero del de Guerra”, notificándole la resolución adoptada en consenso con "Prelados, Ministros y personas graues zelosas de mi seruicio”, de cobrar de todos los oficios, “assi de mi prouisión como de la de mis Virre-

3 GONZÁLEZ BELTRÁN, Jesús Manuel, "Haciendas municipales en la Edad Moderna. Funciones y usos”, La administración municipal en la Edad Moderna, Actas de la V reunión científica. Asociación española de Historia Moderna, vol. II. Servicio de Publicaciones de la Universidad de Cádiz, 1999, pp. 191-216.

4 Influencia que, según Domínguez Ortíz, no conllevó necesariamente dejación por parte de Felipe IV, DOMíNGUEZ ORTÍZ, Antonio, Política y Hacienda de Felipe IV, Madrid, 1960, p. 167: “se equivocan quienes creen que Felipe IV fue un pelele en manos de su ministro, que con tercerías y diversiones lo mantuvo alejado de sus obligaciones. Concretamente en los asuntos de Hacienda la intervención personal y directa del Rey es cosa que no ofrece duda".

En esta misma línea van los estudios realizados por STRADLING, R. A., Felipe IVy el Gobierno de España. 1621-1665, Madrid, Cátedra, 1989, este autor pone empeño en rescatar la figura de Felipe IV confiriéndole importancia y sobre todo independencia a sus actuaciones, sin tener en cuenta la influencia que sobre él pudieron ejercer sus validos. Así lo referencia BUSTOS RODRÍGUEZ, Manuel, en la Revista Trocadero, $\mathrm{n}^{\circ} 2$, Universidad de Cádiz, 1990, pp. 279-281, al aludir a la obra Stradling.

5 BUSTOS RODRÍGUEZ, Manuel, De la Monarquía Hispánica a la crisis del Antiguo Régimen, Sílex, Madrid, 2007, p. 54, alude a los diversos impuestos existentes en esta época, con los que se pretendía reducir el monto de deudas de la Corona, y entre ellos por supuesto, como impuesto de tipo vario, queda contemplado el de la media anata. 
yes, Capitanes generales, Gobernadores, Presidentes, Consejos, Tribunales, Títulos, Ciudades, Villas, y Lugares” y de todas las mercedes hechas por El o por cualquiera de

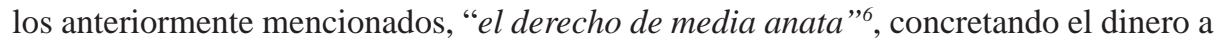
pagar, según qué oficio se ejerza o de qué merced se disfrute, a quién deben abonar la cantidad y en qué momento7. El dinero recogido sería destinado exclusivamente a "la prouision de la Armada Real, y guerra contra hereges e Infieles”.

La Cédula estipula que en el plazo de un mes los Cogedores deberían remitir lo recaudado al Receptor General de la Cruzada de la Cabeza del Partido en cuestión, determinando que por su gestión debían beneficiarse de "medio por ciento en la distancia de diez leguas, y vno por ciento en la de veinte leguas y en llegando dicha distancia a treinta leguas y de alli adelante se les ha de hazer bueno a razon de vno y medio por ciento”. El Receptor General, ante el escribano, debería entregarles la carta de pago correspondiente y por su parte remitir, en el plazo de ocho días, relación del total recibido, con expresa mención de qué lugares y personas.

El incumplimiento de todo lo dispuesto en la Cédula conllevaría la pena correspondiente de 50000 maravedís.

El tenor de la Cédula concreta que los que fuesen elegidos y nombrados por Alcaldes Ordinarios de Hermandad y Regidores debían pagar media anata en la décima que pagaban por servicios anuales, deduciendo dicha décima de la cantidad en que se estimasen dichos oficios, especificando la cantidad y décima a pagar en función del número de vecinos del lugar, quedando de la siguiente manera:

\section{LUGARES DE 100 VECINOS}

\begin{tabular}{|l|c|c|}
\hline \multicolumn{1}{|c|}{ OFICIO } & CANTIDAD & DÉCIMA \\
\hline $\begin{array}{l}\text { Alcalde Ordinario y de Hermandad } \\
\text { por el estado de los hijosdalgo }\end{array}$ & 15 ducados & $\begin{array}{c}1 \text { ducado y } \\
\text { medio. }\end{array}$ \\
\hline $\begin{array}{l}\text { Alcalde Ordinario y de Hermandad } \\
\text { del estado de los hombres buenos }\end{array}$ & 7 ducados y medio & $\begin{array}{c}8 \text { reales y } \\
1 \text { cuartillo. }\end{array}$ \\
\hline
\end{tabular}

6 El cobro de este derecho se inició por vez primera en 1631 y según queda recogido por DOMÍNGUEZ ORTÍZ, A., en Política y Hacienda de Felipe IV, Madrid, 1960, pp. 333-342: En el Archivo Histórico Nacional, Estado, libro 871, del cual se conserva igualmente una copia en el ms. 11030 de la B.N. hojas 279.380, se conserva relación de la Hacienda Real durante los veinte primeros años del reinado de Felipe IV, realizada con probabilidad por el contador Tomás de Aguilar. En esta relación se alude al derecho de media anata especificando que contribuían al mismo "todas las personas beneficiadas con mercedes de oficios, ayudas de costa y otras gracias”, calculando que el importe percibido por el cobro de este derecho sería, desde su inicio en 1631 hasta 1640, de 3.000.000 de ducados.

7 DOMínguEZ ORTíZ, A., Política y Hacienda de Felipe IV, op. cit. p. 228: En el impuesto de la media anata se resumió el de la mesada, que sólo quedó en vigor para los eclesiásticos. La media anata se exigía con sumo rigor y sin excepción alguna de todo el que obtenía cargo, oficio o merced real. Sólo se exigía íntegra cuando el cargo era vitalicio, si era anual pagaba sólo el diezmo, si era trienal, el cuarto, etc. La pagaban también los títulos por razón de creación o herencia. 


\section{LUGARES DE 200 VECINOS}

\begin{tabular}{|l|c|c|}
\hline \multicolumn{1}{|c|}{ OFICIO } & CANTIDAD & DÉCIMA \\
\hline Alcaldes de hijosdalgo & 30 ducados & 3 ducados \\
\hline Alcaldes de hombres buenos & 15 ducados & 1 ducado y medio \\
\hline
\end{tabular}

La equivalencia de estas tablas refleja, y además el documento lo refiere expresamente, como un mayor número de vecinos conllevaba una estimación más elevada de cada uno de estos oficios, siendo la equivalencia la de 15 ducados por cada 100 vecinos, y siendo siempre menor la cantidad estipulada para los alcaldes de los hombres buenos, en concreto la mitad, respecto a los alcaldes de los hijosdalgo. El documento precisa igualmente que en aquellos lugares donde el número de vecinos no fuese exactamente de 100, 200, 300, etc. quedándose en cifras intermedias, por ejemplo más de 100 pero menos de 200, se debería ajustar la estimación de la forma más equilibrada, determinando que cuando a una cifra de cada 100 vecinos se sumasen 50 más, se debería cobrar la mitad más de lo que les correspondía, pero estableciendo que la décima en lugares de mayor población nunca superase los 20 ducados para el oficio de Alcalde Ordinario y de Hermandad de los hijosdalgo, y de 10 ducados para el de hombres buenos.

Respecto a otros oficios se establece lo siguiente:

El oficio de Regidor, siempre que fuese anual y no vendido, debería pagar la mitad que el de los Alcaldes, teniendo en cuenta, como se refleja en las tablas anteriores, el estado a que correspondían, hijosdalgo u hombres buenos, y el número de vecinos.

Para el resto de oficios: Fieles, alarifes, medidores, almotacenes, mayordomos y caballeros de sierra, los ayuntamientos/concejos valorarían sus salarios y ganancias, o bien únicamente estas últimas en el caso de no tener salario asignado, pagando la décima parte. El impago podía acarrearles la pérdida del ejercicio de sus oficios. Esta medida sería adoptada con carácter retroactivo desde el día de San Juan de Junio del año anterior de 1631, hasta el día de recepción de la cédula original o de su traslado signado, fijando el plazo límite de abono en un mes contado a partir de la recepción de dicha cédula.

El Cogedor nombrado por los Ayuntamientos y Concejos para proceder en las Bulas de la Santa Cruzada, sería asimismo el encargado de la recepción de la media anata; para tal efecto el escribano del concejo le debería facilitar previamente la lista de las personas elegidas para cada uno de los citados oficios, así como copia de la referida Cédula, con el objeto de que obrase en su poder relación de las personas a quienes debía cobrar y qué cantidades. El Cogedor, tras hacer efectivo el cobro, expediría carta de pago a los interesados, sin la cual éstos no podrían ejercer sus oficios. 


\section{Resolución de la cédula}

El día 27 de enero de 1633 se presentó la Real Cédula ante el cabildo de la ciudad de Cádiz ${ }^{8}$, estando presentes los siguientes señores:

\begin{tabular}{|l|c|}
\hline \multicolumn{1}{|c|}{ ASISTENTES AL CABILDO } & OFICIO \\
\hline Ldo. Alonso de Cossio Mogrovejo & Alcalde mayor \\
\hline Capitán Pedro de Lao & Regidor \\
\hline Capitán Francisco Marrufo de Negrón & Regidor \\
\hline Nuño de Villavicencio & Regidor \\
\hline Juan Bravo de Laguna & Regidor \\
\hline Capitán Juan Bautista Manito & Regidor \\
\hline Alcaide Juan González de Albelda & Regidor \\
\hline Fernando de la Cerda y Olivares & Regidor \\
\hline Juan Álvarez Paje & Regidor \\
\hline Clemente de Guiñiga & Regidor \\
\hline Pedro Cuemo Garracín & Regidor \\
\hline Cap. Rodrigo de Villavicencio y Negrón & Regidor \\
\hline Juan de Uarte & Regidor \\
\hline Fernando González de Cubas & Regidor $^{10}$ \\
\hline Miguel Díaz de Acosta & Escribano mayor del Ayuntamiento ${ }^{11}$ \\
\hline
\end{tabular}

En dicha sesión, tras la lectura del documento, se acordó elegir diputados para que se encargasen del cumplimiento de lo mandado ${ }^{12}$, saliendo elegidos el Capitán Pedro de Lao y el Alcaide Juan González de Albelda.

Días más tarde, concretamente en el cabildo celebrado el 31 de enero, fue nombrado receptor de la media anata, tal y como se indicaba en la Cédula, Antonio Pérez, receptor de las bulas, a quien debían indicarle quienes habían sido nombrados para desempeñar cada uno de los oficios, para así saber a quien debía cobrar el derecho de media anata.

Al mes siguiente, en sesión de cabildo del día 12 de febrero, fue nombrado contador de la media anata Francisco Manito, regidor de la ciudad.

El día 24 de febrero Don Alonso de Cossio Mogrovejo, alcalde mayor, mandó, mediante un auto, a los señores regidores que en el plazo determinado debían informar al escribano quienes ostentaban cada uno de los oficios, para así poder cobrarles el derecho. En caso de no recibir dicha información se les impondría una pena de 10000 maravedís a cada uno, destinados al derecho de la media anata, sumando a dicha cantidad los posibles daños que pudiera acarrear la demora en el cumplimiento del auto. La misma pena sería aplicada al escribano en caso de no trasladar esta notificación a cada uno de los señores regidores.

A partirdel mismo día 24 de febrero Miguel Díaz, escribano mayor, hizo notificación del anterior auto a cada uno de los regidores. A continuación expondremos en

8 En el Libro de Actas del Archivo Histórico Municipal de Cádiz, citado anteriormente, encontramos la misma relación de personas asistentes al cabildo. Los nombres los incluimos en el mismo orden como aparecen citados en el cuaderno.

9 Era regidor y alguacil mayor en Cádiz y su Obispado.

10 Los "caballeros regidores" estaban obligados a asistir al cabildo, su ausencia conllevaba pagar una multa de dos ducados.

11 En la relación de asistentes al cabildo se aprecia claramente la alusión a apellidos de destacada y reconocida presencia en la sociedad gaditana del siglo XVII. Al respecto puede consultarse el estudio de BUSTOS RODRÍGUEZ, M., “Oligarquía urbana y negocio mercantil en el Cádiz de la Edad Moderna: El clan de los Villavicencio”, en Anales de la Universidad de Cádiz, II, 1985, pp. 175-189.

12 La elección se realizaba al azar, el regidor más antiguo, Fernando González de Cubas, sacaba de la "caxeta de suertes" “dos de las bolillas” con los nombres de los elegidos. 
un cuadro cada una de las notificaciones, indicando la fecha en que se hicieron, nombre del regidor y cargos u oficios que pudieron nombrar, así como año de nombramiento y persona nombrada para cada oficio:

\begin{tabular}{|c|c|c|c|c|}
\hline FECHA & REGIDOR & $\begin{array}{l}\text { SUERTE DE } \\
\text { OFICIOS }\end{array}$ & AÑ̃ & $\begin{array}{c}\text { PERSONA } \\
\text { NOMBRADA }\end{array}$ \\
\hline 24-II-1633 & $\begin{array}{l}\text { Bartolomé Estupiñán } \\
\text { de Oria13 }\end{array}$ & - & & - \\
\hline 24-II-1633 & Juan Álvarez Paje. & $\begin{array}{l}\text {-Escribano de } \\
\text { sacas. }\end{array}$ & 1631 & $\begin{array}{l}\text {-Luis Díaz de } \\
\text { Acosta. }\end{array}$ \\
\hline 24-II-1633 & $\begin{array}{l}\text { Capitán Lorenzo } \\
\text { de Herrera Betancor. }\end{array}$ & $\begin{array}{l}\text {-Escribano } \\
\text { de la Aduana. } \\
\text {-Alarife. }\end{array}$ & 1631 & $\begin{array}{l}\text {-Agustín Díaz } \\
\text { de Acosta. } \\
\text {-Fco. García } \\
\text { el viejo. }\end{array}$ \\
\hline 24-II-1633 & $\begin{array}{l}\text { Xacome de Soberanes } \\
\text { y Quirós. }\end{array}$ & $\begin{array}{l}\text {-Escribano } \\
\text { de la Aduana. } \\
\text {-Alcalde de } \\
\text { carpintero. }\end{array}$ & 1632 & $\begin{array}{l}\text {-Agustín Díaz } \\
\text { de Acosta. } \\
\text {-Cristóbal } \\
\text { Marroquín. }\end{array}$ \\
\hline 25-II-1633 & $\begin{array}{l}\text { Nuño de } \\
\text { Villavicencio. }\end{array}$ & $\begin{array}{l}\text {-Alcalde de } \\
\text { confiteros. } \\
\text {-Diputado de } \\
\text { cárcel. } \\
\text {-Alcalde de } \\
\text { sastre. } \\
\text {-Alcalde de } \\
\text { sastre. } \\
\text {-Alcalde de } \\
\text { zapateros. } \\
\text {-Alcalde de } \\
\text { toneleros. } \\
\text {-Diputado de } \\
\text { sanidad. } \\
\text {-Alcalde de } \\
\text { sastre.14 } \\
\text {-Alcalde de } \\
\text { jubeteros. }\end{array}$ & $\begin{array}{l}1631 \\
1632 \\
1632 \\
1633 \\
1633 \\
1633 \\
1633 \\
1633 \\
1633\end{array}$ & $\begin{array}{l}{ }^{15} \\
-{ }^{16} \\
-{ }^{17} \\
\text {-Fco. Martínez } \\
\text {-Martín } \\
\text { Lozano. } \\
\text { - }{ }^{18} \\
\text {-Pedro } \\
\text { Machorro19 } \\
\text {-Francisco } \\
\text { Martín. } \\
\text {-20 }\end{array}$ \\
\hline
\end{tabular}

13 No le corresponde suerte de oficios por llevar únicamente tres días como regidor.

14 Le correspondía la suerte al regidor Don Juan Estupiñán de Oria pero al estar ausente, por enfermedad, lo nombró Don nuño de Villavicencio.

15 Quedó Vacante por considerar que este cargo no era rentable.

16 Quedó vacante por considerar que el oficio solamente servía para interceder por los pobres en las visitas que por Pascuas se realizan a la cárcel.

17 Este oficio les tocó conjuntamente a D. Nuño de Villavicencio y al regidor Pedro Antonio de Baeza, pero no nombraron a nadie.

18 No nombró ya que nadie lo solicitó.

19 La suerte de este oficio le correspondía al regidor Francisco Fernández de Ángulo, pero al estar ausente, y en virtud de su poder, nombró a Pedro Machorro junto a otros tres pilotos más de los que no conocía sus nombres. Entre los cuatro pagarían lo que les correspondiese.

20 No nombró a nadie por no haber jubeteros, ya que los sastres hacían los jubones. 


\begin{tabular}{|c|l|c|c|c|}
\hline \multirow{5}{*}{ 25-II-1633 } & $\begin{array}{l}\text {-Francisco Manito. } \\
\text {-Juan Andrea } \\
\text { Fontani. }\end{array}$ & - & - & - \\
-Capitán Pedro de & $\begin{array}{l}\text { Lao. } \\
\text {-Capitán Juan } \\
\text { Bautista Manito. } \\
\text { - Alcaide Juan Glez. } \\
\text { de Albelda. }\end{array}$ & - & - \\
-Simón de Soberanis. \\
$\begin{array}{l}\text {-Capitán D. Rodrigo } \\
\text { de Villavicencio }\end{array}$
\end{tabular}

Al mes siguiente, entre los días 2 y 4 de marzo de 1633 el escribano, Miguel Díaz de Acosta, notificaría lo estipulado en el auto del día 24 de febrero a otra serie de personas $^{22}$, al Capitán Pascual Leonissio, Alguacil mayor perpetuo de la ciudad, y a los regidores: Juan Andrea Santoni, Fernando de la Cerda y Olivares, Francisco Manito, Jerónimo Blanquero, Juan González de Albelda, Francisco de Aguirre, Pedro de Chaves, Juan Gómez Espínola, Juan Bautista Manito, Fernando González de Cubas, Rodrigo de Villavicencio, Juan Bravo de Laguna y Francisco Marrufo de Negrón, según puede comprobarse en el cuadro adjunto.

\begin{tabular}{|c|c|c|c|c|}
\hline FECHA & $\begin{array}{l}\text { CARGO Y } \\
\text { NOMBRE } \\
\end{array}$ & $\begin{array}{c}\text { SUERTE DE } \\
\text { OFICIOS }\end{array}$ & AÑO & $\begin{array}{c}\text { PERSONA } \\
\text { NOMBRADA }\end{array}$ \\
\hline $\begin{array}{l}2-I I I- \\
1633\end{array}$ & $\begin{array}{l}\text { Alguacil } \\
\text { Mayor, } \\
\text { Capitán } \\
\text { Pascual } \\
\text { Leonissio }\end{array}$ & $\begin{array}{l}\text {-Diputado para } \\
\text { redención de } \\
\text { censos }^{23} \\
\text {-Alcalde de } \\
\text { carpinteros } \\
\text {-Alcalde de } \\
\text { guarnicionero }{ }^{24}\end{array}$ & 1632 & $\begin{array}{c}- \\
\text {-Andrea Doria }\end{array}$ \\
\hline
\end{tabular}

21 Estos regidores expusieron ante el escribano que verían las suertes de oficios y diputaciones que les tocaran e informarían de las personas nombradas para cada uno de ellos.

22 No se hace mención en el documento a las razones que motivaron que esta notificación se hiciese días más tarde. La referencia a esta nueva notificación va incluida en la parte final del cuaderno, con la que éste concluye. No obstante hemos optado por incluirla en este punto, antes de la valoración de los oficios, por considerarlo oportuno.

23 Para "la redençión de los çensos a imponer de la obra pía que ynstituyó el capitan Esteban Hilton, regidor que fue desta çiudad, difunto y que no se ofreció redimir ningún çenso ni bolbello a imponer”. 24 "guarnicionero, pabonadores y doradores y talabarteros". 


\begin{tabular}{|c|c|c|c|c|}
\hline $\begin{array}{c}2-\text { III- } \\
1633\end{array}$ & $\begin{array}{c}\text { Regidor, } \\
\text { Juan Andrea } \\
\text { Santoni }\end{array}$ & $\begin{array}{l}\text {-Alcalde de } \\
\text { sombrereros } \\
\text {-Alc. confiteros } \\
\text {-Alcalde de } \\
\text { pastelero } \\
\text {-Alcalde de } \\
\text { hereros } \\
\text {-Alc. de sedero y } \\
\text { gorrero } \\
\text {-Alcalde de } \\
\text { pastelero }\end{array}$ & $\begin{array}{l}1631 \\
1632 \\
1632 \\
1633 \\
1633 \\
1633\end{array}$ & \begin{tabular}{l}
\multicolumn{1}{c}{-} \\
\multicolumn{1}{c}{-} \\
-Ant. Figuera \\
-Juan Arias de \\
Valdés \\
-Juan Díaz \\
-Francisco de \\
Japuerta.
\end{tabular} \\
\hline $\begin{array}{l}2-\text { III- } \\
1633\end{array}$ & $\begin{array}{l}\text { Regidor, } \\
\text { Fernando de } \\
\text { la Cerda y } \\
\text { Olivares }\end{array}$ & $\begin{array}{l}\text { - Alcalde de } \\
\text { atahoneros } \\
\text {-Alc. tejedores } \\
\text { de tocas } \\
\text {-Fiel de las } \\
\text { carnicerías } \\
\text {-Alcalde de } \\
\text { calceteros }{ }^{25} \\
\text {-Alcalde de } \\
\text { tejedores tocas } \\
\text {-Alcalde de } \\
\text { Alarifes } \\
\text {-Mayordomo } \\
\text { de propios y } \\
\text { receptor de la } \\
\text { carnicería }\end{array}$ & $\begin{array}{l}1631 \\
1631 \\
1632 \\
1632 \\
1632 \\
1633 \\
1633\end{array}$ & $\begin{array}{l}\text { - } \\
\text {-Antonio } \\
\text { Suárez } \\
\text {-Diego de Castilla } \\
\text { - } \\
\text {-Antonio Suárez } \\
\text {-Juan Beato de } \\
\text { Rojas } \\
\text {-Martín de } \\
\text { Hasarreta }\end{array}$ \\
\hline $\begin{array}{l}2-\text { III- } \\
1633\end{array}$ & $\begin{array}{l}\text { Regidor, } \\
\text { Francisco } \\
\text { Manito }\end{array}$ & $\begin{array}{l}\text {-Alcalde de } \\
\text { curtidor } \\
\text {-Receptor de } \\
\text { la alcabala del } \\
\text { viento } \\
\text {-Contador de } \\
\text { la alcabala del } \\
\text { viento } \\
\text {-Alcalde de } \\
\text { alarifes } \\
\text {-Alcalde de } \\
\text { coleteros }\end{array}$ & $\begin{array}{l}1632 \\
1632 \\
1633\end{array}$ & $\begin{array}{l}\text {-26 } \\
\text {-Agustín Díaz de } \\
\text { Acosta } \\
\text {-Francisco de } \\
\text { Salazar } \\
\text {-Francisco García } \\
\text { - }\end{array}$ \\
\hline
\end{tabular}




\begin{tabular}{|c|c|c|c|c|}
\hline $\begin{array}{l}2-\mathrm{III}- \\
1633\end{array}$ & $\begin{array}{l}\text { Regidor, } \\
\text { Jerónimo } \\
\text { Blanquero }\end{array}$ & $\begin{array}{l}\text {-Alcalde de } \\
\text { serero y visitar } \\
\text { la çera en el } \\
\text { Aduana } \\
\text {-Alcalde de } \\
\text { jubeteros } \\
\text {-Alcalde de } \\
\text { confitero }\end{array}$ & $\begin{array}{l}1632 \\
1632 \\
1633\end{array}$ & $\begin{array}{l}\text {-Juan Arias de } \\
\text { Valdés }\end{array}$ \\
\hline $\begin{array}{l}3-\text { III- } \\
1633\end{array}$ & $\begin{array}{c}\text { Regidor, Juan } \\
\text { Duarte }\end{array}$ & $\begin{array}{l}\text {-Alcalde de } \\
\text { tahoneros }\end{array}$ & 1633 & - \\
\hline $\begin{array}{l}3-\mathrm{III}- \\
1633\end{array}$ & $\begin{array}{c}\text { Alcaide, Juan } \\
\text { González de } \\
\text { Albelda }\end{array}$ & $\begin{array}{l}\text {-Fiel del } \\
\text { contraste } \\
\text {-Fiel de la } \\
\text { carnicería }{ }^{27} \\
\text {-Receptor de la } \\
\text { alcabala de la } \\
\text { carne } \\
\text {-Alarife } \\
\text {-Alcalde de } \\
\text { cerrajeros y } \\
\text { herreros } \\
\text {-Alarife } \\
\text {-Alcalde de } \\
\text { cerrajeros y } \\
\text { herreros } \\
\text {-Receptor de } \\
\text { la alcabala del } \\
\text { viento en el } \\
\text { aduana }{ }^{30} \\
\text {-Contador de } \\
\text { la alcabala del } \\
\text { viento } \\
\text {-Alcalde de } \\
\text { herreros y } \\
\text { cerrajeros } \\
\text {-Alcalde de } \\
\text { curtidores } \\
\text {-Alcalde de } \\
\text { guarnicioneros, } \\
\text { pabonadores, } \\
\text { doradores y } \\
\text { talabarteros }\end{array}$ & $\begin{array}{l}1631 \\
1631 \\
1631 \\
1631 \\
1631 \\
1632 \\
1632 \\
1633 \\
\\
1633 \\
1633 \\
1633 \\
1633\end{array}$ & 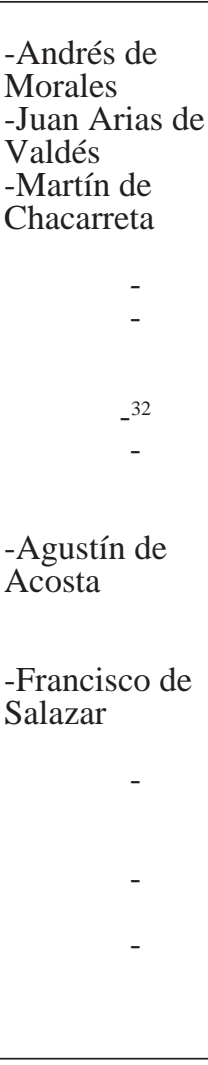 \\
\hline
\end{tabular}

27 Nombra por Don Esteban Hilton Santoni, regidor de la ciudad.

28 Se hace cargo del oficio pero le correspondía al regidor Don Esteban Hilton Santoni.

29 Correspondiente al regidor Don Esteban Hilton Santoni.

30 Correspondiente a Don Esteban Hilton, al igual que el oficio siguiente de contador.

31 Correspondiente a Don Esteban Hilton.

32 No pudo hacer nombramiento por estar ausente en Madrid. 


\begin{tabular}{|c|c|c|c|c|}
\hline $\begin{array}{l}3-\text { III- } \\
1633\end{array}$ & $\begin{array}{l}\text { Regidor } \\
\text { Francisco de } \\
\text { Aguirre }\end{array}$ & $\begin{array}{l}\text {-Alcalde de } \\
\text { coleteros } \\
\text {-Alcalde de } \\
\text { calceteros } \\
\text {-Alcalde de } \\
\text { esparteros } \\
\text {-Suerte de las } \\
\text { medidas del } \\
\text { vino, aceite, miel } \\
\text {-Suerte de } \\
\text { medidas de cal } \\
\text {-Alcalde de } \\
\text { herreros y } \\
\text { cerrajeros }\end{array}$ & $\begin{array}{l}1631 \\
1632 \\
1632 \\
1633 \\
1633 \\
1633\end{array}$ & $\begin{array}{l}\text { - } \\
- \\
- \\
\text {-Francisco Díaz } \\
\text {-Francisco de } \\
\text { Acosta }\end{array}$ \\
\hline $\begin{array}{l}3 \text {-III- } \\
1633\end{array}$ & $\begin{array}{c}\text { Regidor Pedro } \\
\text { de Chaves }\end{array}$ & $\begin{array}{l}\text {-Alcalde de } \\
\text { espaderos } \\
\text {-Alcalde de } \\
\text { pasteleros } \\
\text {-Contraste } \\
\text {-Alcalde de } \\
\text { confiteros } \\
\text {-Alcalde de } \\
\text { confiteros }\end{array}$ & $\begin{array}{l}1631 \\
1631 \\
1632 \\
1632 \\
1633\end{array}$ & \begin{tabular}{l}
\multicolumn{1}{c}{ - } \\
-Francisco Ruiz \\
-Juan Granado, \\
platero \\
-Gaspar de Barros \\
-Gaspar de Barros
\end{tabular} \\
\hline $\begin{array}{l}3 \text {-III- } \\
1633\end{array}$ & $\begin{array}{l}\text { Regidor } \\
\text { Juan Gómez } \\
\text { Espínola }\end{array}$ & $\begin{array}{l}\text {-Serrete de paños } \\
\text {-toneleros } \\
\text {-Alcalde de } \\
\text { pasteleros }\end{array}$ & $\begin{array}{l}1631 \\
1631 \\
1631\end{array}$ & $\begin{array}{c}{ }^{33} \\
- \\
- \text { Guillermo Pérez }\end{array}$ \\
\hline $\begin{array}{l}3 \text {-III- } \\
1633\end{array}$ & $\begin{array}{l}\text { Regidor Juan } \\
\text { Bautista } \\
\text { Manito }\end{array}$ & $\begin{array}{l}\text {-Alcalde de } \\
\text { confiteros } \\
\text {-Alcalde de } \\
\text { tahoneros } \\
\text {-Alcalde de } \\
\text { guarnicioneros, } \\
\text { pabonadores y } \\
\text { doradores } \\
\text {-Alcalde de } \\
\text { talabarteros } \\
\text {-Medidas de } \\
\text { vino, aceite y } \\
\text { miel y frutas } \\
\text {-Medida de la cal } \\
\text {-Alcalde de } \\
\text { carpintero }\end{array}$ & $\begin{array}{l}1631 \\
1632 \\
1632 \\
1633\end{array}$ & $\begin{array}{l}\text {-Calisto de Alfaro } \\
\text {-Francisco Díaz } \\
\text {-Domingo } \\
\text { Hurtado } \\
\text { - }\end{array}$ \\
\hline
\end{tabular}

33 No hizo nombramiento pero desempeñó la función Pedro Gómez, tundidor. 


\begin{tabular}{|c|c|c|c|c|}
\hline $\begin{array}{l}3 \text {-III- } \\
1633\end{array}$ & $\begin{array}{l}\text { Regidor } \\
\text { Fernando } \\
\text { González de } \\
\text { Cubas }\end{array}$ & $\begin{array}{l}\text {-Alcalde de } \\
\text { jubeteros } \\
\text {-Diputado de } \\
\text { sanidad } \\
\text {-Alcalde de } \\
\text { curtidores } \\
\text {-Alcalde de } \\
\text { jubeteros }\end{array}$ & $\begin{array}{l}1631 \\
1632 \\
1632 \\
1633\end{array}$ & $\begin{array}{c}- \\
\text {-Pedro Machorro } \\
- \\
-\end{array}$ \\
\hline $\begin{array}{l}3 \text {-III- } \\
1633\end{array}$ & $\begin{array}{c}\text { Regidor } \\
\text { Rodrigo de } \\
\text { Villavicencio } \\
\text { y Negrón }\end{array}$ & $\begin{array}{l}\text {-Alcalde de } \\
\text { espadero } \\
\text {-Escribano de } \\
\text { fincas } \\
\text {-Alcalde de } \\
\text { sombrereros } \\
\text {-Alcalde de } \\
\text { platero } \\
\text {-Alcalde de } \\
\text { sastre }\end{array}$ & $\begin{array}{l}1631 \\
1632 \\
1632 \\
1632 \\
1633\end{array}$ & $\begin{array}{l}- \\
\text {-Luis Díaz de } \\
\text { Acosta }^{34} \\
- \\
- \\
-\end{array}$ \\
\hline $\begin{array}{l}3 \text {-III- } \\
1633\end{array}$ & $\begin{array}{c}\text { Regidor Juan } \\
\text { Bravo de } \\
\text { Laguna }\end{array}$ & $\begin{array}{l}\text {-Alcalde de } \\
\text { carpinteros } \\
\text {-Alcalde de } \\
\text { sombrereros } \\
\text {-Contraste } \\
\text {-Alcalde de } \\
\text { tahoneros }\end{array}$ & $\begin{array}{l}1631 \\
1632 \\
1633 \\
1633\end{array}$ & \begin{tabular}{l}
-Cristóbal \\
Marroquín \\
- \\
-Andrés de \\
Morales \\
\multicolumn{1}{c}{ - }
\end{tabular} \\
\hline $\begin{array}{l}4-\text { III- } \\
1633\end{array}$ & $\begin{array}{c}\text { Regidor Fco. } \\
\text { Marrufo de } \\
\text { Negrón }\end{array}$ & $\begin{array}{l}\text {-Diputado de } \\
\text { sanidad } \\
\text {-Alcalde de } \\
\text { sederos } \\
\text {-Alcalde de } \\
\text { coleteros } \\
\text {-Alcalde de } \\
\text { cordoneros }\end{array}$ & $\begin{array}{l}1631 \\
1631 \\
1632 \\
1633\end{array}$ & $\begin{array}{c}\text {-Pedro Machorro } \\
- \\
- \\
-\end{array}$ \\
\hline
\end{tabular}

Con fecha 25 de Febrero de 1633 y ante el señor Licenciado Don Alonso de Cossio Mogrovejo, Alcalde mayor de Cádiz por su Majestad, el Capitán Pedro de Lao y el Alcaide Juan González de Albelda, regidores perpetuos de la ciudad y diputados en su cabildo, que habían sido elegidos para efectuar la valoración de los distintos oficios que al principio de cada año nombra el ayuntamiento, presentaron la siguiente valoración ${ }^{35}$ :

34 Escribano mayor del cabildo

35 Los datos incluidos en la tabla están expuestos siguiendo el mismo orden con el que aparecen en el documento.

Según la valoración presentada la equivalencia de monedas sería: 1 real = 34 maravedís; 1 ducado = 374 maravedís; 1 ducado $=11$ reales. 


\begin{tabular}{|c|c|c|c|}
\hline OFICIO & VALOR ANUAL & $\begin{array}{l}\text { TERCIA PARTE } \\
\text { AÑADIDA }\end{array}$ & $\begin{array}{c}\text { DECIMA } \\
\text { PARTE DE } \\
\text { MEDIA ANATA }\end{array}$ \\
\hline Contraste $^{36}$ & $\begin{array}{c}300 \text { reales/ } 10200 \\
\text { maravedís }\end{array}$ & $\begin{array}{c}400 \text { reales/13600 } \\
\text { maravedís }\end{array}$ & $\begin{array}{c}40 \text { reales } / 1360 \\
\text { maravedís }\end{array}$ \\
\hline Herrete de Paños & $\begin{array}{c}50 \text { reales } / 1700 \\
\text { maravedís }\end{array}$ & 2266 maravedís $^{37}$ & 226 maravedís \\
\hline Alcalde de Zapateros & $\begin{array}{c}100 \text { reales } / 3400 \\
\text { maravedís }\end{array}$ & 4533 maravedís & 453 maravedís \\
\hline Alcalde de Toneleros & $\begin{array}{c}30 \text { reales } / 1020 \\
\text { maravedís }\end{array}$ & 1360 maravedís $^{38}$ & 136 maravedís \\
\hline $\begin{array}{l}\text { Fiel de las medidas de } \\
\text { vino, aceite y miel }\end{array}$ & $\begin{array}{l}100 \text { reales } / 3400 \\
\text { maravedís }\end{array}$ & 4533 maravedís & 453 maravedís \\
\hline Diput. & $\begin{array}{l}200 \text { reales } / 6800 \\
\text { maravedís }\end{array}$ & 9066 maravedís & 906 maravedís \\
\hline Alcalde de cereros & $\begin{array}{l}50 \text { reales } / 1700 \\
\text { maravedís }\end{array}$ & 2266 maravedís & 226 maravedís \\
\hline Diputado de Sanidad ${ }^{39}$ & $\begin{array}{c}200 \text { reales } / 6800 \\
\text { maravedís }\end{array}$ & 9066 maravedís & 906 maravedís \\
\hline $\begin{array}{l}\text { Escribano de la } \\
\text { Aduana }\end{array}$ & $\begin{array}{c}1100 \\
\text { reales/37400 } \\
\text { maravedís }\end{array}$ & 49866 maravedís & 4986 maravedís \\
\hline $\begin{array}{c}\text { Escribano de sacas y } \\
\text { cosas vedadas }\end{array}$ & $\begin{array}{c}400 \text { reales } / 13600 \\
\text { maravedís }\end{array}$ & 18133 maravedís & 1813 maravedís \\
\hline $\begin{array}{c}\text { Mayordomo de la } \\
\text { ciudad }\end{array}$ & $\begin{array}{c}50 \\
\text { ducados/18700 } \\
\text { maravedís }\end{array}$ & 24933 maravedís & 2493 maravedís \\
\hline $\begin{array}{l}\text { Receptor de la } \\
\text { carnicería }\end{array}$ & $\begin{array}{c}60 \\
\begin{array}{c}\text { ducados } / 22440 \\
\text { maravedís }\end{array}{ }^{40} \\
\end{array}$ & 29920 maravedís & 2992 maravedís \\
\hline Fiel de la carnicería & $\begin{array}{c}60 \\
\begin{array}{c}\text { ducados/22440 } \\
\text { maravedís }\end{array}{ }^{41} \\
\end{array}$ & 29920 maravedís & 2992 maravedís \\
\hline $\begin{array}{c}\text { Receptor de la alcabala } \\
\text { de la carne }\end{array}$ & $\begin{array}{c}330 \text { reales } / 11220 \\
\text { maravedís }\end{array}$ & 14960 maravedís & 1496 maravedís \\
\hline $\begin{array}{c}\text { Fiel de la alcabala del } \\
\text { viento }\end{array}$ & $\begin{array}{c}30 \text { ducados/330 } \\
\text { reales/11220 } \\
\text { maravedís }\end{array}$ & 14960 maravedís & 1496 maravedís \\
\hline $\begin{array}{l}\text { Receptor de la alcabala } \\
\text { del viento }\end{array}$ & $\begin{array}{c}30 \text { ducados/ } 330 \\
\text { reales/11220 } \\
\text { maravedís }\end{array}$ & 14960 maravedís & $\begin{array}{c}1496 \\
\text { maravedís }^{42}\end{array}$ \\
\hline
\end{tabular}

36 Sellar pesos y medidas.

37 La tercia parte añadida serían 566 maravedís.

38 El documento por error alude a 1300 maravedís, aunque en la cifra que anexa al margen rectifica e indica la suma correcta, 1360 maravedís.

39 Nombran para este cargo a cuatro pilotos que guardarían la bahía, impidiendo que "echen el lastre que traen las naos en ella".

4022400 es la cifra anotada en el documento, pero según la equivalencia del momento debería aparecer la de 22440 maravedís. El escriba del cuadernillo comete sin duda un error ya que además las cantidades siguientes, el tercio añadido y la décima, están calculadas según la cifra de 22440 y no la de 22400.

41 Vuelve a cometer el mismo error anterior. La cifra debe ser 22440 maravedís en lugar de 22400 que es lo que sin lugar a dudas aparece escrito en el documento.

42 Una vez más encontramos otro error, 1446 en lugar de la cifra correcta 1496. 


\begin{tabular}{|c|c|c|c|}
\hline $\begin{array}{l}\text { Diputados para } \\
\text { arrendar las rentas }\end{array}$ & - & - & 0 \\
\hline Diputados del pósito ${ }^{44}$ & - & - & 0 \\
\hline $\begin{array}{l}\text { Diputados de la } \\
\text { Obra Pía }\end{array}$ & - & - & 0 \\
\hline $\begin{array}{c}\text { Diputados de la Fiesta } \\
\text { del Corpus }\end{array}$ & - & - & 0 \\
\hline $\begin{array}{c}\text { Diputados para la } \\
\text { Fiesta de los Santos } \\
\text { Patronos San Servando } \\
\text { y San Germán } \\
\end{array}$ & 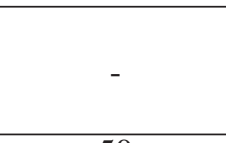 & - & 0 \\
\hline Depositario del pósito & $\begin{array}{c}50 \\
\text { ducados/18700 } \\
\text { maravedís }\end{array}$ & 24933 maravedís & 2493 maravedís \\
\hline Diputados de cárcel $^{46}$ & - & - & 0 \\
\hline $\begin{array}{l}\text { Diputados de Menores } \\
\text { y Tutelas }\end{array}$ & - & - & 0 \\
\hline Diputados de Boticas & - & - & 0 \\
\hline $\begin{array}{l}\text { Diputados para otorgar } \\
\text { escrituras de censos }{ }^{47}\end{array}$ & - & - & 0 \\
\hline Obreros mayores & - & - & 0 \\
\hline $\begin{array}{l}\text { Alcaldes de } \\
\text { cordoneros }^{48}\end{array}$ & - & - & 0 \\
\hline $\begin{array}{l}\text { Alcaldes de } \\
\text { tahoneros }^{49}\end{array}$ & - & - & 0 \\
\hline $\begin{array}{l}\text { Alcaldes de } \\
\text { carpinteros }^{50}\end{array}$ & $\begin{array}{c}50 \text { reales } / 1700 \\
\text { maravedís }\end{array}$ & 2266 maravedís & 226 maravedís $^{51}$ \\
\hline Alcalde de sastre & $\begin{array}{c}40 \text { reales } / 1360 \\
\text { maravedís }\end{array}$ & 1813 maravedís & 183 maravedís $^{52}$ \\
\hline Alcalde de jubeteros ${ }^{53}$ & - & - & 0 \\
\hline Alcaldes de calceteros & - & - & 0 \\
\hline
\end{tabular}

43 Este oficio no tenía salario ni aprovechamientos, sino carga, por lo que no tenía que tasar. 44 Como en el caso anterior este oficio tampoco tenía salario ni aprovechamientos.

45 Esta obra la instituyó Luis Moreno “para repartir a pobres vergonzantes”.

46 Se nombra entre los regidores con la finalidad de asistir en la composición de causas de pleitos por deudas.

47 "Que se redimen de la obra pia de Steban Chriltan, que subcede por muerte de ultimo sucesor y se nombran por no perder el derecho".

48 Este oficio aunque se sorteaba no llegaba a nombrarse a nadie ya que no existía en la ciudad.

49 No había nadie ejerciese o quisiera ejercer este oficio.

50 Se nombraban dos, las cantidades apuntadas se refieren únicamente a uno.

51 Cada uno de los alcaldes de carpinteros.

52 Cifra especificada en el cuaderno para la décima que debía pagar cada uno de los alcaldes de sastres.

53 Se sorteaba por no perder el derecho pero en la ciudad no existía el oficio. 


\begin{tabular}{|c|c|c|c|}
\hline Alarife de albañilería $^{54}$ & $\begin{array}{c}100 \text { reales/3400 } \\
\text { maravedís }\end{array}$ & 4533 maravedís & 453 maravedís \\
\hline $\begin{array}{c}\text { Alcaldes de } \\
\text { confiteros }^{55}\end{array}$ & - & - & 0 \\
\hline Alcaldes de pasteleros $_{\text {Alcaldes de parteros }}^{56}$ & - & - & 0 \\
\hline Alcaldes de plateros & - & - & 0 \\
\hline Alcalde de sacas & $\begin{array}{c}200 \text { reales/6800 } \\
\text { maravedís }\end{array}$ & 9066 maravedís & 906 maravedís \\
\hline
\end{tabular}

Al siguiente día de presentar esta valoración, el día 26 de febrero de 1633, el Alcalde mayor de la ciudad mandaría que se hiciese una copia signada de la tasación y autos realizados, para enviarla a Don Pedro Marmolejo.

\section{Conclusiones}

-La Cédula es una clara muestra de la política llevada a cabo durante el reinado de Felipe IV, política encaminada a obtener beneficios económicos que contribuyesen a paliar el endeudamiento de la Corona.

-El documento evidencia cómo la ciudad de Cádiz no escapó a dicha política y por ello, acatando lo dispuesto en la Cédula real, se vieron obligados al pago del impuesto de media anata.

-Sin lugar a dudas se perseguía recaudar dinero, que iría destinado a proveer a la Armada Real en la guerra contra los infieles, pero intentando que la recaudación fuese proporcionada, para ello se tendría en cuenta el número de vecinos de cada lugar y la mayor o menor importancia de cada uno de los oficios; según estas premisas en el tenor documental se precisa lo que debían abonar Alcaldes y Regidores, siendo más relevantes los primeros y destacando, en ambos oficios, los pertenecientes al estamento superior de hijosdalgo respecto al de hombres buenos.

La valoración del resto de oficios sería realizada por los ayuntamientos. En el caso de Cádiz el oficio de mayor valor anual, según puede comprobarse en la tabla presentada, era el de escribano de la aduana, estimado en 37400 maravedís.

- Los diputados gaditanos, elegidos al azar, encargados del cumplimiento de lo dispuesto en la Cédula fueron el Capitán Pedro de Lao y el Alcaide Juan González de Albelda.

- En una misma persona, Antonio Pérez, recayó la función de cogedor para proceder en las Bulas de la Santa Cruzada y receptor del derecho de media anata.

-El documento anexado a la Cédula, realizado en Cádiz, donde se plasman los pasos seguidos para llevar a efecto lo en ella dispuesto, alude a los apellidos más relevantes de la sociedad gaditana del siglo diecisiete: Cossio, Estupiñán, González de Cubas, Hilton, Marrufo de Negrón, Santoni, Villavicencio ...

54 Valoraban las casas.

55 Se sorteaba pero el número era insuficiente y además nadie quería el cargo.

56 Nunca se habían nombrado dado que la ciudad únicamente contaba con dos. 

ANEXO 



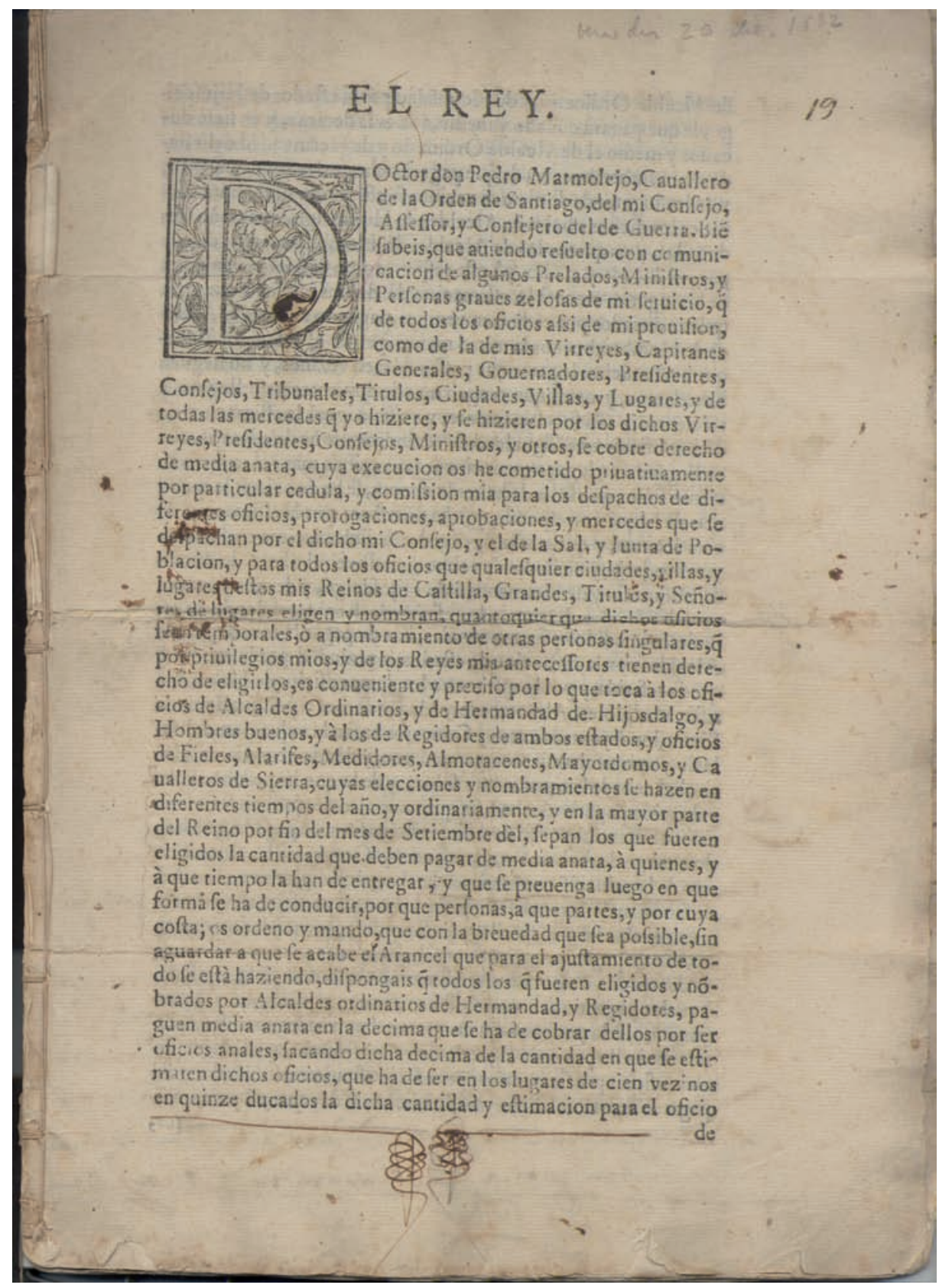

Biblioteca del Seminario de Cádiz. Cédula Real de Felipe IV. Fol.1rº. 


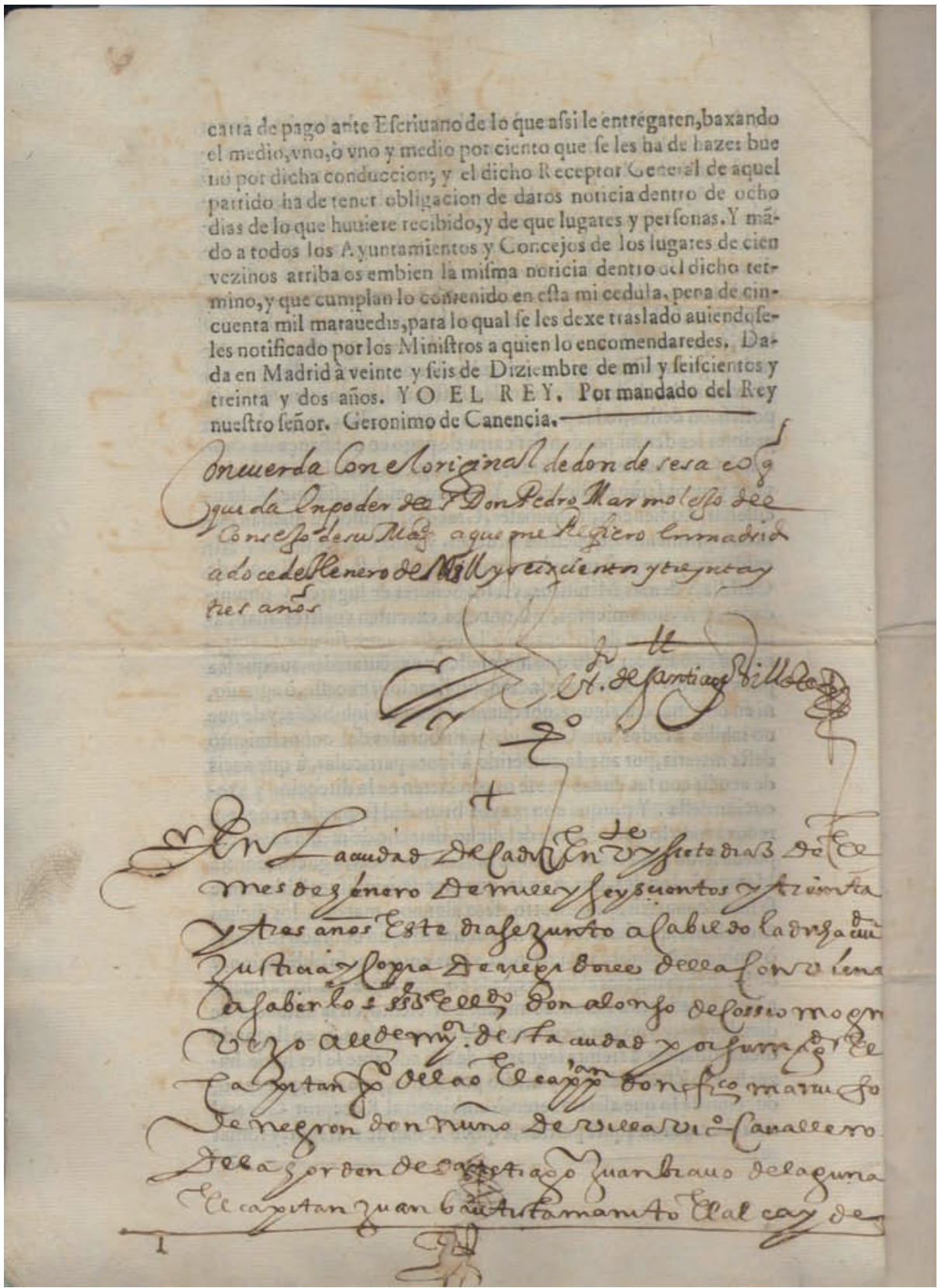

Biblioteca del Seminario de Cádiz. 


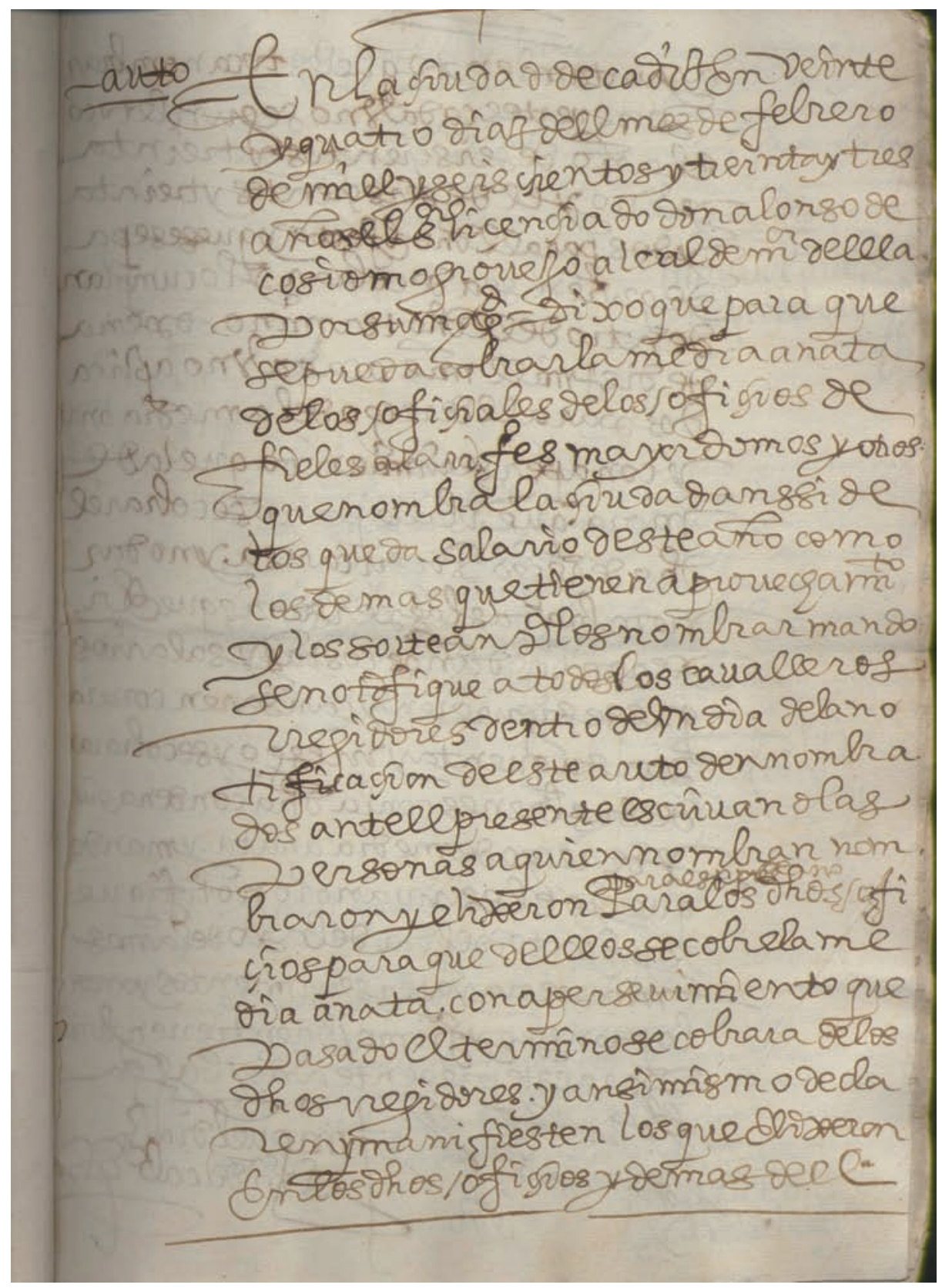

Biblioteca del Seminario de Cádiz. 


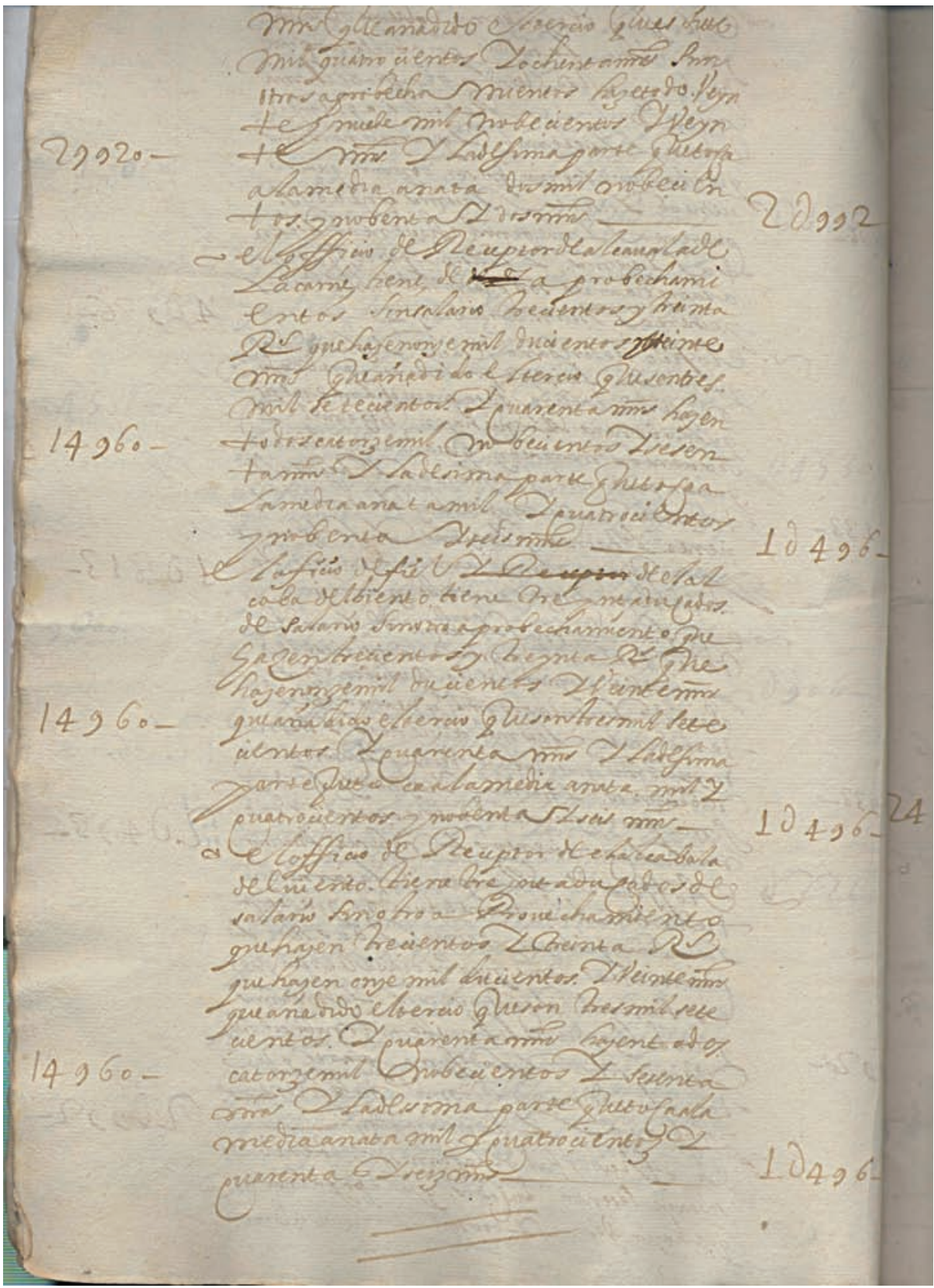

Biblioteca del Seminario de Cádiz. 
Cédula de Felipe IV sobre el derecho de la media anata

187

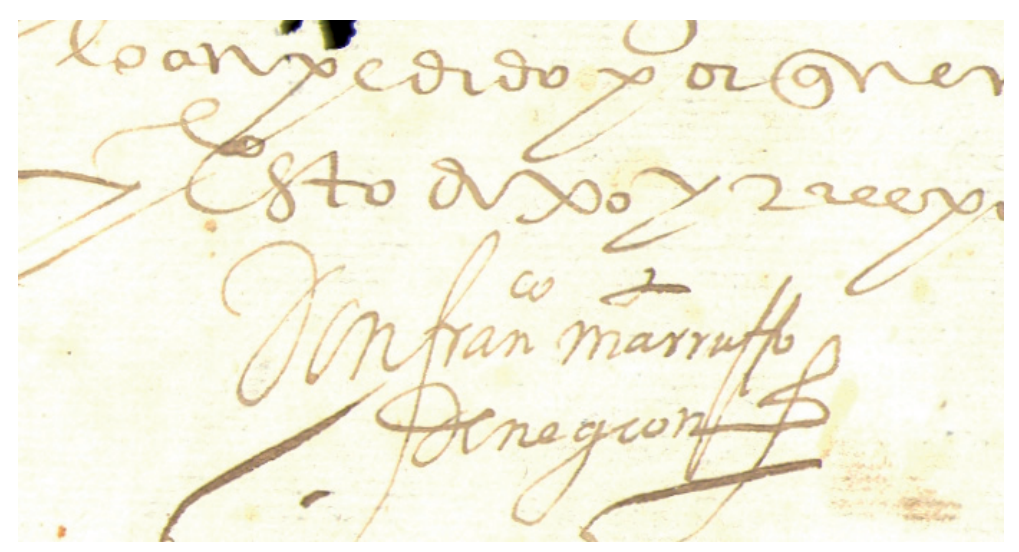

Firma de Don Francisco Marrufo de Negrón.

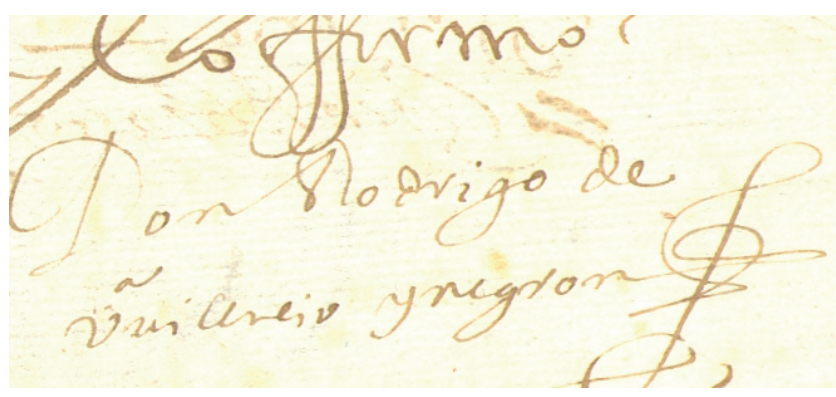

Firma de Don Rodrigo de Villavicencio y Negrón.

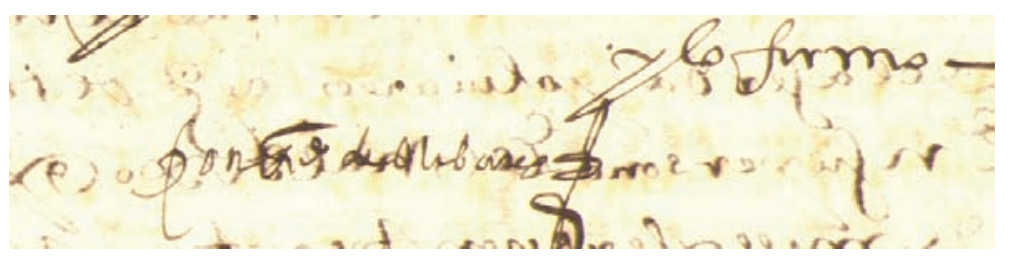

Firma de Don Fernando de la Cerda y Olivares. 


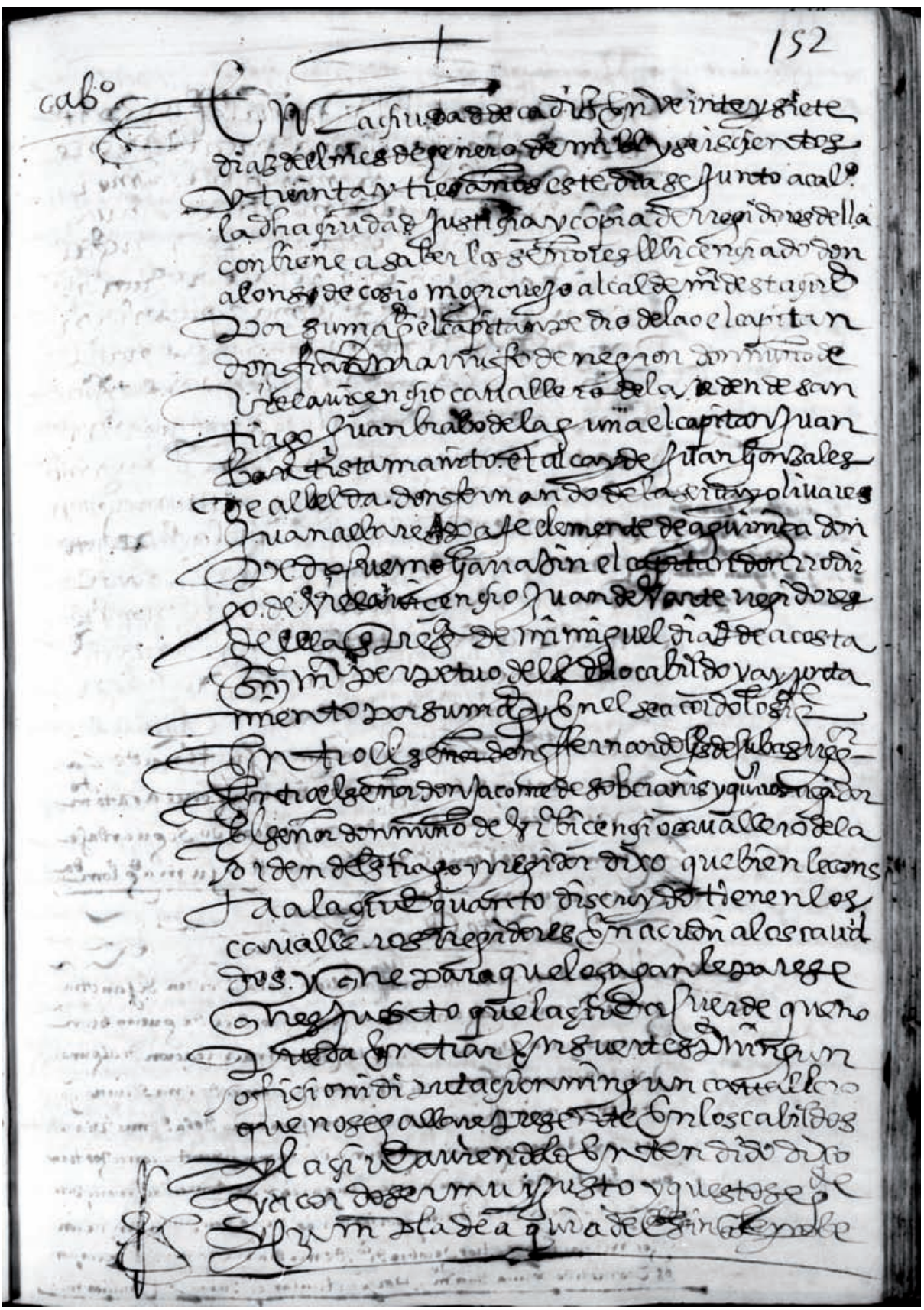

Archivo Histórico Municipal de Cádiz. Libro de Actas n 10016, fol. 152rº 


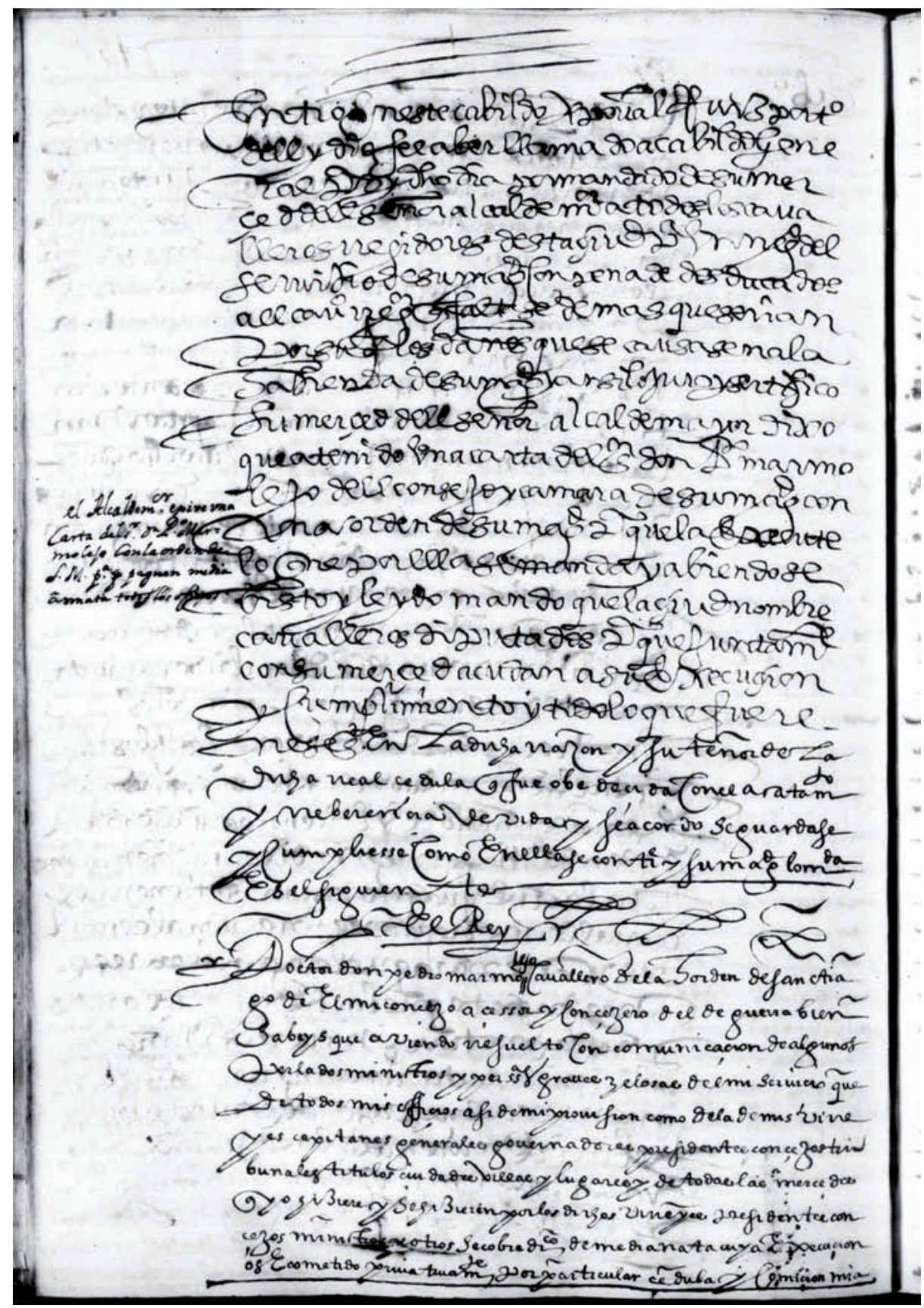

AHMC. Libro de Actas no 10016, fol. 152vº. 
